\title{
The -675 4G/5G polymorphism at the Plasminogen Activator Inhibitor 1 (PAI-1) gene modulates plasma Plasminogen Activator Inhibitor 1 concentrations in response to dietary fat consumption
}

\author{
P. Pérez-Martínez ${ }^{1}$, M. D. Adarraga-Cansino ${ }^{1}$, R. A. Fernández de la Puebla ${ }^{1}$, A. Blanco-Molina ${ }^{1}$, \\ J. Delgado-Lista ${ }^{1}$, C. Marín ${ }^{1}$, J. M. Ordovás ${ }^{2}$, J. López-Miranda ${ }^{1}$ and F. Pérez-Jiménez ${ }^{1}$ \\ ${ }^{1}$ Lipids and Atherosclerosis Research Unit, Hospital Universitario Reina Sofia, CIBER, Fisiopatologia, Obesidad y Nutricion, \\ Avda. Menendez Pidal, s/n. 14004 Cordoba, Spain \\ ${ }^{2}$ Nutrition and Genomics Laboratory, US Department of Agriculture Human Nutrition Research Center on Aging at Tufts \\ University, Boston, MA 02111, USA \\ (Received 29 March 2007 - Revised 10 July 2007 - Accepted 30 July 2007)
}

The objective of the study was to determine whether Plasminogen Activator Inhibitor Type 1 (PAI-1) -675 4G/5G polymorphism is associated with the response of functional plasma PAI-1 concentrations to changes in the amount and quality of dietary fat in healthy subjects. PAI-1 is the major inhibitor of fibrinolysis, and a lower level of fibrinolytic activity could be implicated in an increased risk of IHD. Fifty-nine healthy Spanish volunteers (ten 4G/4G homozygotes, twenty-eight heterozygotes $4 \mathrm{G} / 5 \mathrm{G}$ and twenty-one $5 \mathrm{G} / 5 \mathrm{G}$ homozygotes) consumed three diets for periods of 4 weeks each: a SFA-rich diet (38\% fat, $20 \%$ SFA), followed by a carbohydrate-rich diet (30\% fat, 55\% carbohydrate) and a MUFA-rich diet (38\% fat, $22 \%$ MUFA) according to a randomized crossover design. At the end of each dietary period plasma lipid and functional plasma PAI-1 concentrations were determined. Subjects carrying the $4 \mathrm{G}$ allele (4G/4G and $4 \mathrm{G} / 5 \mathrm{G})$ showed a significant decrease in PAI-1 concentrations after the MUFA diet, compared with the SFA-rich and carbohydrate-rich diets (genotype $\times$ diet interaction: $P=0.028$ ). 5G/5G homozygotes had the lowest plasma PAI-1 concentrations compared with $4 \mathrm{G} / 4 \mathrm{G}$ and $4 \mathrm{G} / 5 \mathrm{G}$ subjects (genotype: $P=0.002$ ), without any changes as a result of the amount and the quality of the dietary fat. In summary, no differences in plasma PAI- 1 concentration response were found after changes in dietary fat intake in $5 \mathrm{G} / 5 \mathrm{G}$ homozygotes, although these subjects displayed the lowest concentrations of PAI-1. On the other hand, carriers of the $4 \mathrm{G}$ allele are more likely to hyper-respond to the presence of MUFA in the diet because of a greater decrease in PAI-1 concentrations.

PAI-1 -675 4G/5G polymorphism: Nutrigenetics: Dietary fat: Functional PAI-1: MUFA-rich diet

Plasminogen Activator Inhibitor Type 1 (PAI-1) is a protein that reduces plasma fibrinolytic capacity. Its production is encoded by a gene with several polymorphisms. The presence of the $4 \mathrm{G}$ allele at a common insertion-deletion polymorphism in the promoter of the PAI-1 gene has been associated with elevated plasma PAI-1 concentration and activity ${ }^{1}$. Carriers of the $4 \mathrm{G}$ allele $(4 \mathrm{G} / 4 \mathrm{G}$ and $4 \mathrm{G} / 5 \mathrm{G})$ may be at increased risk of $\mathrm{IHD}^{2,3}$, but this could depend on interactions with other environmental factors, which may explain why results obtained from Western populations have been ambiguous. On the other hand, previous studies have shown that the presence of the $5 \mathrm{G}$ allele in the $-6754 \mathrm{G} / 5 \mathrm{G}$ polymorphism decreases gene expression, which predisposes to lower plasma PAI-1 concentrations ${ }^{5}$. A recent meta-analysis suggests the importance of this polymorphism because of a per-allele relative risk of about 1.06 of coronary disease in individuals with the $-6754 \mathrm{G}$ variant of the PAI-1 gene 6 .
However, it is known that plasma PAI-1 concentration is influenced by many other factors, including diet, smoking, exercise, obesity, fasting plasma TAG concentrations and the insulin resistance syndrome ${ }^{7,8}$. In this context, Sanders et al. have demonstrated in a group of middle-age men that postprandial variations in fibrinolytic activity are modulated by the PAI-1 $-6754 \mathrm{G} / 5 \mathrm{G}$ genotype but not by the fat content of a meal ${ }^{9}$. Some data show that the substitution of dietary SFA by MUFA causes a decrease in plasma PAI-1 concentrations ${ }^{10,11}$. In this respect, nutrigenetics is emerging as a multidisciplinary field that focuses on studying the interactions between nutritional and genetic factors, and health outcomes ${ }^{11}$. However, it has not been determined whether the presence of the $-6754 \mathrm{G} / 5 \mathrm{G}$ polymorphism modifies the response to different diets. In view of the previous evidence, the aim was to determine whether this polymorphism is related to the response of functional plasma PAI-1 concentrations to changes in the amount and quality of dietary fat in healthy subjects.

Abbreviations: CHO, carbohydrate; PAI-1, Plasminogen Activator Inhibitor Type 1.

* Corresponding author: Dr Pablo Pérez-Martínez, fax + 34957 218250, email pablopermar@yahoo.es 


\section{Experimental methods}

\section{Subjects and diet}

Fifty-nine healthy Spaniard normolipaemic volunteers (thirty men and twenty-nine women) participated in the study. All subjects were less than 30 years of age, with no evidence of any chronic illness or unusually high levels of physical activity. Mean initial BMI was 21 and remained constant throughout the experimental period. They were encouraged to maintain their regular physical activity and lifestyle, and were asked to record in a diary any event that could affect the outcome of the study. They consumed $<30 \mathrm{~g} / \mathrm{d}$ alcohol during the study.

The study design included an initial $28 \mathrm{~d}$ period during which all subjects consumed a SFA-enriched diet containing $15 \%$ protein, $47 \% \mathrm{CHO}$ and $38 \%$ fat $(20 \% \mathrm{SFA}, 12 \%$ MUFA, $6 \%$ PUFA). After this period, thirty subjects received a MUFA-enriched diet for $28 \mathrm{~d}$ in a randomized, crossover design. This diet contained $15 \%$ protein, $47 \% \mathrm{CHO}$ and $38 \%$ fat $(<10 \%$ SFA, $6 \%$ PUFA, $22 \%$ MUFA $)$. The MUFA-enriched diet was followed for $28 \mathrm{~d}$ by a high-CHO diet containing $15 \%$ protein, $55 \% \mathrm{CHO}$ and $<30 \%$ fat ( $<10 \%$ SFA, $6 \%$ PUFA, $12 \%$ MUFA). The other twentynine subjects received the CHO diet before the MUFA diet. Cholesterol content remained constant (under $300 \mathrm{mg} / \mathrm{d}$ ) during the three periods. Virgin olive oil, used for cooking, salad dressing and as a spread, provided $80 \%$ of the MUFA diet. The $\mathrm{CHO}$ component of the high-CHO diet was based on the consumption of biscuits, jam and bread. Butter and palm oil were used during the SFA dietary period.

The Human Investigation Review Committee at Reina Sofia University Hospital approved the study. The compositions of the experimental diets have been described previously ${ }^{12}$. Dietary compliance was verified by analysing the fatty acids in LDL-cholesterol esters at the end of each dietary period ${ }^{13}$.

\section{Blood sampling and biochemical determinations}

Venous blood for analysis of insulin, glucose, lipid and lipoprotein was collected from the subjects in tubes containing EDTA after a $12 \mathrm{~h}$ overnight fast at the end of each dietary period. Each analysis was performed in triplicate. Total cholesterol, HDL-cholesterol, LDL-cholesterol and TAG were assayed by procedures described previously ${ }^{14-17}$.

\section{Plasminogen Activator Inhibitor Type 1 activity}

For analysis, blood samples anticoagulated with sodium citrate were collected and PAI-1 activity (control range 3-15 IU/ml) was determined according to Chemielewska et al. using a commercial kit (Spectrolyse (fibrin); Bio-Pool, Umea, Sweden $)^{18}$.

\section{Genetic analysis}

DNA extraction was performed using standard procedures. The PAI-1 genotypes of the $-6754 \mathrm{G} / 5 \mathrm{G}$ polymorphism were determined by means of an allele-specific PCR, which was performed for each allele determination according to conditions previously described ${ }^{19}$.

\section{Statistical analyses}

Statistical analyses were carried out using the SPSS statistical package version 13 (SPSS Inc., Chicago, IL, USA). ANOVA for repeated measures was used to analyse the differences in plasma lipid and PAI-1 activity between dietary phases. When statistically significant effects were demonstrated, Tukey's post hoc test was used to identify between-group differences. Correlation analysis was performed with Pearson's coefficient of correlation. A value of $P<0.05$ was considered significant. All data are presented as means and standard deviations.

\section{Results}

The study sample comprises a group of fifty-nine volunteers. Of these, ten were $4 \mathrm{G} / 4 \mathrm{G}$ homozygotes, twenty-eight were $4 \mathrm{G} / 5 \mathrm{G}$ heterozygotes and twenty-one were $5 \mathrm{G} / 5 \mathrm{G}$ homozygotes. Fatty acid composition during each dietary period was analysed on the cholesterol ester fraction of plasma LDL, as we have previously published ${ }^{20}$. An enrichment in palmitic acid was observed following the SFA diet, and in oleic acid after the MUFA diet, suggesting that there had been good adherence to the dietary protocol. No differences were recorded between genotypes with respect to age, BMI, smoking status, TAG, HDL-cholesterol and apo A-1 plasma concentration at baseline. However, 4G/4G homozygotes showed higher concentrations of total cholesterol $(P=0.03)$, LDLcholesterol $(P=0 \cdot 01)$ and apo B $(P=0 \cdot 01)$ than did $4 \mathrm{G} / 5 \mathrm{G}$ and $5 \mathrm{G} / 5 \mathrm{G}$ subjects.

Total cholesterol, LDL-cholesterol and HDL-cholesterol were significantly reduced $(P<0.001)$ following the consumption of the CHO and MUFA diets as compared with the SFAenriched diet (Table 1). An effect of the interaction of genotype and diet was observed, because the consumption of a MUFA diet decreases plasma PAI-1 concentrations in subjects carrying the $4 \mathrm{G}$ allele $(4 \mathrm{G} / 4 \mathrm{G}, 4 \mathrm{G} / 5 \mathrm{G})$ more than the SFA and $\mathrm{CHO}$ diets $(P=0.028$; Fig. 1). An effect associated with genotype was also noted, the $5 \mathrm{G} / 5 \mathrm{G}$ homozygote subjects showed the lowest plasma PAI-1 concentrations, without any changes as a result of the amount and quality of the dietary fat $(P=0 \cdot 002$; Fig. 1$)$.

\section{Discussion}

The present results show that the consumption of a MUFArich diet for 4 weeks decreases plasma PAI-1 concentrations in subjects carrying the $4 \mathrm{G}$ allele $(4 \mathrm{G} / 4 \mathrm{G}, 4 \mathrm{G} / 5 \mathrm{G})$ in the PAI-1 gene promoter, compared with the SFA- and CHOrich diets, while the $5 \mathrm{G} / 5 \mathrm{G}$ homozygotes showed the lowest plasma PAI-1 concentrations, without any changes resulting from the amount and quality of the dietary fat.

In agreement with previous studies which used different experimental designs ${ }^{10-12,21}$, the present findings confirm that the isoenergetic substitution of dietary SFA by MUFA is associated with lower plasma levels of the fibrinolysis inhibitor. To the best of our knowledge, the current study is the first to examine the association between the $-6754 \mathrm{G} / 5 \mathrm{G}$ polymorphism at the PAI-1 gene and functional plasma PAI-1 concentrations in response to dietary intervention. Our most relevant finding, which has not been described before, is the observation that there exists an interaction between 
Table 1. Plasma lipid, lipoprotein and Plasminogen Activator Inhibitor Type 1 (PAl-1) activity values after each dietary period

(Mean values and standard deviations)

\begin{tabular}{|c|c|c|c|c|c|c|c|}
\hline & \multicolumn{2}{|c|}{ SFA diet } & \multicolumn{2}{|c|}{$\mathrm{CHO}$ diet } & \multicolumn{2}{|c|}{ MUFA diet } & \multirow[b]{2}{*}{$P$ value } \\
\hline & Mean & SD & Mean & SD & Mean & SD & \\
\hline Total cholesterol (mmol/l) & $4 \cdot 27$ & 0.3 & $3 \cdot 6^{*}$ & 0.2 & $3 \cdot 74^{*}$ & 0.3 & 0.001 \\
\hline LDL-cholesterol (mmol/l' & $2 \cdot 80$ & 0.6 & $2 \cdot 32^{*}$ & 0.5 & $2 \cdot 34^{\star}$ & 0.6 & 0.001 \\
\hline HDL-cholesterol (mmol/l) & $1 \cdot 12$ & 0.3 & $0.99^{*}$ & $0 \cdot 2$ & $1.03^{\star}$ & 0.1 & 0.001 \\
\hline $\mathrm{TAG}(\mathrm{mmol} / \mathrm{l})$ & 0.77 & 0.2 & 0.78 & 0.2 & 0.79 & 0.3 & 0.437 \\
\hline apo A-1 (mmol/l) & $3 \cdot 67$ & 0.01 & $2 \cdot 78^{\star}$ & $0 \cdot 1$ & $2 \cdot 86^{\star}$ & 0.01 & 0.001 \\
\hline apo B $(\mathrm{mmol} / \mathrm{l})$ & 1.88 & 0.3 & $1 \cdot 70^{\star}$ & 0.2 & $1 \cdot 70^{\star}$ & 0.2 & 0.001 \\
\hline PAI-1 activity (UA/ml) & 7 & 2 & 7 & 2 & $5^{\star} \dagger$ & 2 & 0.05 \\
\hline
\end{tabular}

$\mathrm{CHO}$, carbohydrate.

Mean values were significantly different from those of the SFA diet (ANOVA test for repeated measures): ${ }^{\star} P<0.05$

Mean value was significantly different from that of the $\mathrm{CHO}$ diet (ANOVA test for repeated measures): $\dagger P<0.05$.

the intake of dietary fat and the presence of the $4 \mathrm{G}$ allele. Thus, the expected reduction in plasma PAI-1 concentrations was observed only in subjects carrying the $4 \mathrm{G}$ allele but not in the $5 \mathrm{G} / 5 \mathrm{G}$ homozygotes, although these subjects showed the lowest plasma levels. The lack of a differential response to different dietary fats which we observed in $5 \mathrm{G} / 5 \mathrm{G}$ subjects is in agreement with a previous study that tested the response after a test meal that was very high in butter fat ${ }^{22}$. In that study, subjects carrying the $4 \mathrm{G}$ allele also showed an increase in PAI-1 activity. These data confirm the findings of previous reports that PAI-1 activity in $5 \mathrm{G} / 5 \mathrm{G}$ homozygotes is lower than in subjects who carry one or more $4 \mathrm{G}$ alleles ${ }^{23,24}$. In a previous study, Sanders et al. have demonstrated a lower plasma TAG concentration in the subjects homozygous for the $5 \mathrm{G}$ allele ${ }^{25}$. All these data suggest that the PAI-1 promoter $-6754 \mathrm{G}$ variant is associated with a higher risk of myocardial infarction. However, subjects are more likely to hyper-respond to the presence of MUFA in the diet because of a greater decrease in PAI-1 concentrations.

A potential mechanism to explain the observed changes in PAI-1 concentrations resulting from different fat intakes lies in the identification by Eriksson et al. ${ }^{26}$ of a VLDL-inducible

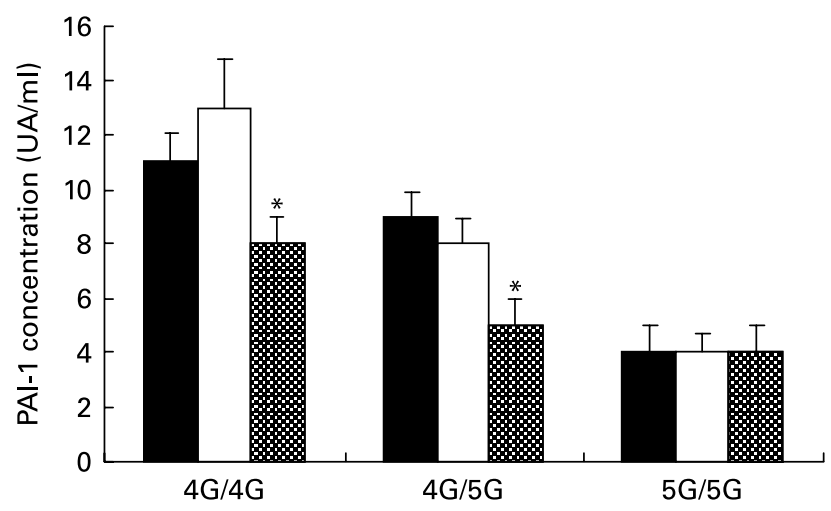

Fig. 1. Functional Plasminogen Activator Inhibitor Type 1 (PAI-1) levels $(\mathrm{UA} / \mathrm{ml})$ during the three dietary periods $(\mathbf{\square}, \mathrm{SFA} ; \square$, carbohydrate $(\mathrm{CHO})$ 8. MUFA) according to genotype (4G/4G, $n$ 10; 4G/5G, $n$ 28; 5G/5G, $n$ 21). Values are means with their standard deviations depicted by vertical bars. Mean values were significantly different from those of the SFA and $\mathrm{CHO}$ diet: ${ }^{\star} P<0.05$. $P$ genotype $=0.002 ; P$ diet $=0.003 ; P$ genotype $\times$ diet interaction $=0.028$. factor that binds a putative VLDL response element located to residues -672 to -657 . The VLDL-induced factor was found to bind to the region adjacent to and partly overlapping the binding site of the $5 \mathrm{G}$ allele. Competition between the $5 \mathrm{G}$ allele-specific transcriptional repressor $\operatorname{protein}^{5}$ and the VLDL-induced factor could explain the $4 \mathrm{G} / 5 \mathrm{G}$ allele-specific relations between VLDL TAG and PAI- 1 activity levels in plasma. In addition, competitive binding between the $5 \mathrm{G}$ allele-specific repressor and the common transcriptional activator could explain the differences in basal transcriptional activity $^{26}$. This competition between the activator and the repressor will not be present or decreased in $4 \mathrm{G} / 4 \mathrm{G}$ and $4 \mathrm{G} / 5 \mathrm{G}$ subjects, supporting the lower overall levels of circulating PAI-1 observed in the preesnt study for $5 \mathrm{G} / 5 \mathrm{G}$ homozygotes. Alternatively, Chen et $a .^{27}$ have identified a fatty acid response element, distinct from the VLDL response element ${ }^{26}$, and shown a NEFA-induced increase in the expression of PAI-1 independent of previously reported effects mediated by TAG or lipoproteins. This could mediate the differential responses observed for the various dietary fatty acids in the current study. However, PAI-1 regulation appears to be highly complex and probably tissue dependent and this hypothesis needs to be further tested in vitro and in vivo.

In summary, the presence of the $4 \mathrm{G}$ allele at the PAI-1 gene promoter is associated with higher levels of PAI-1. This group, which makes up $40 \%$ of the general population, is sensitive to reductions in SFA or CHO in the diet intake, and responds with a reduction in plasma PAI-1 concentrations when the recommendation to consume a MUFA-enriched diet is followed. In conclusion, the present study suggests that the cardioprotective effect of a chronic intake of a MUFA diet enriched in olive oil could be due, at least in part, to its protective effect on fibrinolytic activity.

\section{Acknowledgements}

This work was supported by research grants from CIBER (CBO/ 6/03), Instituto de Salud Carlos III; CICYT (SAF 01/2466-C05 04 to F. P.-J., SAF 01/0366 to J. L.-M.), the Spanish Ministry of Health (FIS 01/0449); Fundación Cultural "Hospital Reina Sofía-Cajasur" (to C. M. and P. G.); Consejería de Salud, Servicio Andaluz de Salud (00/212, 00/39, 01/239, 01/243, 02/64, 
02/65, 02/78); Consejería de Educación, Plan Andaluz de Investigación, Universidad de Córdoba and by NIH/NHLBI grant no. HL54776 and contracts 53-K06-5-10 and 58-1950-9-001 from the US Department of Agriculture Research Service.

\section{References}

1. Ye S, Green FR, Scarabin PY, et al. (1995) The 4G/5G genetic polymorphism in the promoter of the plasminogen activator inhibitor-1 (PAI-1) gene is associated with differences in plasma PAI-1 activity but not with risk of myocardial infarction in the ECTIM study. Etude CasTemoins de I'nfarctus du Mycocarde. Thromb Haemost 74, 837-841.

2. Fu L, Jin H, Song K, Zhang C, Shen J \& Huang Y (2001) Relationship between gene polymorphism of the PAI-1 promoter and myocardial infarction. Chin Med J (Engl) 114, 266-269.

3. Boekholdt SM, Bijsterveld NR, Moons AH, Levi M, Buller HR \& Peter RJ (2001) Genetic variation in coagulation and fibrinolytic proteins and their relation with acute myocardial infarction: a systematic review. Circulation 104, 3063-3068.

4. Ridker PM, Hennekens CH, Lindpaintner K, Stampfer MJ \& Miletich JP (1997) Arterial and venous thrombosis is not associated with the $4 \mathrm{G} / 5 \mathrm{G}$ polymorphism in the promoter of the plasminogen activator inhibitor gene in a large cohort of US men. Circulation 95, 59-62.

5. Eriksson P, Kallin B, van't Hooft FM, Bavenholm P \& Hamsten A (1995) Allele-specific increase in basal transcription of the plasminogen-activator inhibitor1 gene is associated with myocardial infarction. Proc Natl Acad Sci U S A 92, 1851-1855.

6. Ye Z, Liu EH, Higgins JP, Keavney BD, Lowe GD, Collins R \& Danesh J (2006) Seven haemostatic gene polymorphisms in coronary disease: meta-analysis of 66,155 cases and 91,307 controls. Lancet 367, 651-658.

7. Cesari M, Sartori MT, Patrassi GM, Vettore S \& Rossi GP (1999) Determinants of plasma levels of plasminogen activator inhibitor-1. Arterioscler Thromb Vasc Biol 19, 316-320.

8. Kohler HP \& Grant PJ (2000) Plasminogen activator inhibitor Type 1 and coronary artery disease. New Engl J Med 342, 1792-1801.

9. Sanders TA, de Grassi T, Acharya J, Miller GJ \& Humphries SE (2004) Postprandial variations in fibrinolytic activity in middleaged men are modulated by plasminogen activator inhibitor I 4G-675/5G genotype but not by the fat content of a meal. Am J Clin Nutr 79, 577-581.

10. Avellone G, Di Garbo V \& Cordova R (1998) Effects of Mediterranean diet on lipid, coagulative and fibrinolytic parameters in two randomly selected population samples in Western Sicily. Nutr Metab Cardiovasc Dis 8, 287-296.

11. Junker R, Pieke B, Schulte H, Nofer R, Neufeld M, Assmann G \& Wahrburg U (2001) Changes in hemostasis during treatment of hypertriglyceridemia with a diet rich in monounsaturated and n-3 polyunsaturated fatty acids in comparison with a low-fat diet. Tromb Res 101, 355-366.

12. López-Segura F, Velasco F, López-Miranda J, et al. (1996) Mounsaturated fatty acid-enriched diet decreases plasma plasminogen activator inhibitor type 1. Arterioscler Thromb Vasc Biol 16, 82-88.

13. Ruiz-Gutiérrez V, Prada JL \& Pérez-Jiménez F (1993) Determination of fatty acid and triacylglycerol composition of human very-low-density lipoproteins. J Chromatogr 622, 117-134.
14. Allain CC, Poon LS, Chan CS, Richmond W \& Fu PC (1974) Enzymatic determination of total serum cholesterol. Clin Chem 20, 470-474.

15. Fossati P \& Prencipe L (1982) Serum triglycerides determined colorimetrically with an enzyme that produces hydrogen peroxide. Clin Chem 28, 2077-2082.

16. Assmann G, Schrierwer H, Schmitz G \& Hagele EO (1983) Quantification of high density lipoprotein cholesterol by precipitation with phosphotungsic acid- $\mathrm{MgCl}_{2}$. Clin Chem 29, 2026-2030.

17. Friedewald WT, Levy RI \& Fredickson DS (1972) Estimation of the concentration of low-density lipoprotein cholesterol in plasma without use of preparative ultracentrifuge. Clin Chem 18, 499-502.

18. Chemielewska J, Ranby M \& Wiman B (1983) Evidence for a rapid inhibitor to tissue plasminogen activator in plasma. Thromb Res 31, 427-436.

19. Morange PE, Henry M, Tregouet D, Granel B, Aillaud MF, Alessi MC \& Juhan-Vague I (2000) The polymorphism in the PAI-1 gene is associated with a higher risk of venous thrombosis in factor V Leiden carriers. Arterioscler Thromb Vasc Biol 20, 1387-1391.

20. Perez-Martinez P, Gomez P, Paz E, Marin C, Gavilan-Moral E, Lopez-Miranda J, Ordovas JM, Fernandez de la Puebla RA \& Perez-Jimenez F (2001) Interaction between smoking and the Sstl polymorphism of the apo C-III gene determines plasma lipid response to diet. Nutr Metab Cardiovasc Dis 11, 237-243.

21. Perez-Jimenez F, Castro P, Lopez-Miranda J, Paz-Rojas E, Blanco A, Lopez-Segura F, Velasco F, Marin C, Fuentes F \& Ordovas JM (1999) Circulating levels of endothelial function are modulated by dietary monounsaturated fat. Atherosclerosis 145, 351-358.

22. Byrne $\mathrm{CD}$, Wareham NJ, Martensz ND, Humphries SE, Metcalfe JC \& Grainger DJ (1998) Increased PAI activity and PAI-1 antigen occurring with an oral fat load: associations with PAI-1 genotype and plasma active TGF-beta levels. Atherosclerosis 140, 45-53.

23. Vaisanen SB, Humphries SE, Luong LA, Penttila I, Bouchard C \& Rauramaa R (1999) Regular exercise, plasminogen activator inhibitor-1 (PAI-1) activity and the $4 \mathrm{G} / 5 \mathrm{G}$ promoter polymorphism in the PAI-1 gene. Thromb Haemost 82, $1117-1120$.

24. van der Bom JG, Bots ML, Haverkate F, Kluft C \& Grobbee DE (2003) The 4G5G polymorphism in the gene for PAI-1 and the circadian oscillation of plasma PAI-1. Blood 101, $1841-1844$.

25. Sanders TA, de Grassi T, Acharya J, Miller GJ \& Humphries SE (2004) Postprandial variations in fibrinolytic activity in middleaged men are modulated by plasminogen activator inhibitor I 4G-675/5G genotype but not by the fat content of a meal. Am J Clin Nutr 79, 577-581.

26. Eriksson P, Nilsson L, Karpe F \& Hamsten A (1998) Very-lowdensity lipoprotein response element in the promoter region of the human plasminogen activator inhibitor- 1 gene implicated in the impaired fibrinolysis of hypertriglyceridemia. Arterioscler Thromb Vasc Biol 8, 20-26.

27. Chen Y, Billadello JJ \& Schneider DJ (2000) Identification and localization of a fatty acid response region in the human plasminogen activator inhibitor-1 gene. Arterioscler Throm Vasc Biol 20, 2696-2701. 